\title{
Impact of Compost Application on Fall-seeded Camelina Yield and Seed Quality
}

\author{
Foteini ANGELOPOULOU ${ }^{1 *}$, Eleni TSIPLAKOU ${ }^{2}$, Dimitrios BILALIS ${ }^{1}$ \\ ${ }^{1}$ Department of Crop Science, Laboratory of Agronomy, Agricultural University of Athens, 75 Iera Odos \\ Str., 11855 Athens, Greece \\ ${ }^{2}$ Department of Animal Science and Aquaculture, Laboratory of Nutritional Physiology and Feeding, 75 \\ Iera Odos Str., 11855 Athens, Greece \\ * corresponding author: fangelo@aua.gr
}

BulletinUASVM Horticulture 76(2) / 2019

Print ISSN 1843-5254, Electronic ISSN 1843-5394

DOI:10.15835/buasvmcn-hort: 2019.0028

\begin{abstract}
Camelina sativa (L). Crantz is a novel promising oilseed plant that can be grown as a spring annual crop or as a winter annual, in milder climates, providing distinct advantages. The objectives of this 3-year study were to evaluate the agronomic potential of fall-seeded camelina in Mediterranean conditions and the effect of compost application on its yield and quality characteristics. The response of fall-seeded camelina to organic fertilization resulted in tripling the seed yield and enhance the weight of seeds, compared to the unfertilized control. Concerning, seed quality characteristics compost application significantly enhanced only seed ash percentage (3.71\%) as compared to control (3.05\%) and lesser the crude fiber, crude protein and oil content. Results indicated that camelina is a feasible winter crop for Southern Greece and further studies must be carried out to optimize its production.
\end{abstract}

Keywords: compost, organic fertilization, seed quality, seed yield, winter Camelina

\section{Introduction}

Camelina (Camelina sativa L. Crantz) is a member of the Brassicaceae family that has garnered the global attention, in current agricultural systems, due to its unique fatty acid profile of seed oil and the environmental, nutritional and industrial benefits. Camelina can either be grown as a spring or winter crop but most of the cultivation and scientific studies are generally focused on spring crop. Notwithstanding, growing camelina as a winter annual crop has noticeable advantages. Planting camelina in the fall will result in earlier emerge in spring which improve plant stand (Obour et al., 2015). Good stand establishment could offer good weed suppression without the use of herbicides, supporting the assertion that it can potentially serve as a low-input crop (Gesch and Cermak,
2011). Besides, fall planting will allow camelina to mature before the onset of hot summer temperatures that can affect seed yield and may be harvested early, allowing soil moisture storage for the subsequent crop (Obour et al., 2015).

Compost use is one of the most important factors, which contribute to increased productivity, crop quality, sustainable agriculture and compared to manure, releases nutrients more slowly which have longer lasting effects (Adugna, 2016). The proper use of organic and inorganic nutrient sources is important to sustain high levels of crop production, while maintaining or enhancing soil and environmental quality. Realizing the potential and the advantages of fall-seeded camelina, fertilization and agronomic requirements need to be standardized in order to optimize productivity and seed quality. 
Table 1. Main effect of fertilization on camelina in quality characteristics (average of years)

\begin{tabular}{lccccc}
\hline \multirow{2}{*}{ Experimental factor } & $\begin{array}{c}\text { Ash } \\
\text { (\% DM) }\end{array}$ & $\begin{array}{c}\text { Crude fiber } \\
\text { (\%DM) }\end{array}$ & $\begin{array}{c}\text { Crude } \\
\text { protein } \\
\text { (\%DM) }\end{array}$ & $\begin{array}{c}\text { Oil content } \\
\text { (\%DM) }\end{array}$ \\
\hline \multirow{3}{*}{ Fertilization } & Compost & $3.71 \mathrm{a}$ & 14,54 & 22,63 & 42,57 \\
& Control & $3.05 \mathrm{~b}$ & 14,89 & 23,30 & 42,70 \\
\cline { 2 - 6 } & LSD & 0.623 & $\mathrm{~ns}$ & $\mathrm{~ns}$ & $\mathrm{~ns}$ \\
\hline
\end{tabular}

When $\mathrm{F}$ test rejected null hypothesis, LSD values $(\mathrm{P}=0.05)$ were calculated. ns: not significant. DM: Dry matter

Table 2. Main effect of fertilization on 1000 seeds weight and seed yield (average of years)

\begin{tabular}{cccc}
\hline \multicolumn{2}{c}{ Experimental factor } & $\begin{array}{c}\mathbf{1 0 0 0} \text { seeds weight } \\
\mathbf{( g )}\end{array}$ & Seed yield (kg ha') \\
\hline \multirow{3}{*}{ Fertilization } & Compost & $1.21 \mathrm{a}$ & $392.74 \mathrm{a}$ \\
& Control & $1.25 \mathrm{~b}$ & $119.03 \mathrm{~b}$ \\
\cline { 2 - 4 } & LSD & 0.015 & 96.311 \\
\hline
\end{tabular}

When $\mathrm{F}$ test rejected null hypothesis, $\mathrm{LSD}$ values $(\mathrm{P}=0.05)$ were calculated. ns: not significant.

\section{Materials and methods}

A three year field study $(2013,2014,2015$ growing seasons) was carried out in Southern Greece in the region of the city Tripoli. The field experiment was arranged in a complete randomized design with three replicates and two treatments (compost $1000 \mathrm{~kg} \mathrm{ha}^{-1}$ and untreated control). Following a preliminary evaluation in 2012 a commercial compost containing $7 \%$ N, 4\% $\mathrm{P}_{2} \mathrm{O}_{5}$ and $7 \% \mathrm{~K}_{2} \mathrm{O}$ was used. The mean temperature and the total precipitation during the study period (November-May) ranged from: a) 2013-2014: $5,4^{\circ} \mathrm{C}$ to $16,1^{\circ} \mathrm{C}$ and $16 \mathrm{~mm}$ to $211 \mathrm{~mm}$ b) $2014-$ 2015: $10,4^{\circ} \mathrm{C}$ to $17,5^{\circ} \mathrm{C}$ and $13 \mathrm{~mm}$ to $151 \mathrm{~mm} \mathrm{c}$ ) 2015-2016: $4,9^{\circ} \mathrm{C}$ to $19,2^{\circ} \mathrm{C}$ and $4 \mathrm{~mm}$ to $114 \mathrm{~mm}$. The soil was a clay loam with $\mathrm{pH} 6.5$, organic matter $1.5 \%$ and total nitrogen $0.10 \%$. Camelina was sown by hand on early November $330 \mathrm{~kg}$ $\mathrm{ha}^{-1}$ ), according to the environmental annual conditions in order to prepare a proper seedbed. The seed quality characteristics determined were: dry matter, ash, crude fiber, crude protein and oil content (AOAC, 1984) and are reported on a dry weight basis as a percent of whole grain. Seed yield was assessed at full maturity (seed moisture content $6-7 \%$ ) by harvesting each plot and the seeds were cleaned and weighed to determine seed yield. One thousand seeds in each plot were counted and weighted to determine 1000 seed weight.

The results were subjected to statistical analysis of variance. Calculations were made in the Statistica 7.0 programme (StatSoft, Tulsa,USA). Differences between treatment means were compared at $\mathrm{P}<5 \%$ in order to find the statistically significant differences.

\section{Results and discussions}

Results revealed a significant increase in the ash content of seed when compost was applied compared with control (Tab. 1). This could be attributed to the increase in seed weight (Tab. 2) and size as a result of improved physical, chemical and nutritional properties of the soil due to organic fertilizer application (Elsheikh and Elzidany, 1997). However, there was no significant difference between compost application and the control concerning crude fiber, crude protein and oil content. Regarding oil content these results are in agreement with studies in flax (Bilalis et al., 2010) and camelina (Joshi et al., 2017) which also use organic fertilization. Notwithstanding, oil content percent $(>42 \%)$ was remarkably higher 
than other studies in fall-seeded camelina (Gesch and Cermak, 2011).

Concerning seed yield and 1000 seeds weight (Tab. 2) there were significant differences between compost application and the unfertilized control. Effects of compost application on soils, such as increasing soil structural stability, improving water holding capacity, air and heat balance, plant water and nutrients availability, decrease of nutrients leaching and reducing erosion and evaporation are well documented and lead to a higher yield safety compared to pure mineral fertilization (Adugna, 2016). Compost application have reported to present a significant positive affect on seed yield and 1000 seeds weight also in spring camelina crop (Bilalis et al., 2017).

\section{Conclusions}

Compost application on fall-seeded camelina can strongly affect its productivity which encourages the adoption of winter camelina in Southern Greece. More experimentation is needed to optimize agronomic practices in organic farming of adopted for fall-seeded camelina production.

\section{References}

1. Adugna G (2018). A review on impact of compost on soil properties, water use and crop productivity. Agricultural Science Research Journal. 4(3): 93-104.

2. Association of Official Analytical Chemists International, (1984): Official Methods of Analysis, 14th edn. AOAC, Arlington,VA.

3. Bilalis D, Karkanis A, Papastylianou P, Patsiali S, Athanasopoulou M, Barla G, Kakabouki I (2010). Response of organic linseed (Linum usitatissimum L.) to the combination of tillage systems, (minimum, conventional and no-tillage) and fertilization practices: Seed and oil yield production. Australian Journal of Crop Science, 4: 700-705.

4. Bilalis D, Roussis I, Fuentes F, Kakabouki I, Travlos I (2017). Organic Agriculture and Innovative Crops under Mediterranean Conditions. Notulae Botanicae Horti Agrobotanici Cluj-Napoca, 45(2): 323-331.

5. Gesch RW, Cermak CS (2011). Sowing date and tillage effects on fall-seeded camelina in the Northern Corn Belt. Agron J, 103(4): 980-987.

6. Joshi SK, Ahamada S, Meher LC, Agarwal A, Nasim M (2017). Growth and yield response of camelina sativa to inorganic fertilizers and farmyard manure in hot semiarid climate of India. Adv. Plants. Agric. Res., 7(3):305309.

7. Obour KA, Sintim YH, Obeng E, Jeliazkov DV (2015). Oilseed Camelina (Camelina sativa L Crantz): Production Systems, Prospects and Challenges in the USA Great Plains. Adv Plants. Agric. Res., 2(2): 00043. 